\title{
Diversity of Airborne Fungi at Pepper Plantation Lembah Bidong, Kuala Terengganu
}

\author{
NUR AINU FARHAH RABAE, SALMAN AZIZ, ASAMOAH FREDERICK OSEI \& SITI \\ NORDAHLIAWATE MOHAMED SIDIQUE* \\ Laboratory for Pest, Disease and Microbial Biotechnology (LAPDiM), Faculty of Fisheries and Food Sciences, \\ Universiti Malaysia Terengganu, 21030 Kuala Nerus, Terengganu, Malaysia \\ *Corresponding author: dahliasidique@umt.edu.my \\ Received: 19 October $2020 \quad$ Accepted: 24 December $2020 \quad$ Published: 31 December 2020
}

\begin{abstract}
Piper nigrum L. is well-known as the king of spices and widely used in various field such as food and medicines. In Malaysia, 98\% of pepper production comes from the state of Sarawak. The National Commodity Policy (2011-2020) targets to increase the pepper plantation area from the current 16,331 ha to 20,110 ha by year 2020 . However, pepper diseases remain as a major challenge in the pepper industry. A great number of airborne fungi pathogen may contribute to a significant economic loss in pepper production. Therefore, this study aims to morphologically identify the diversity of fungi obtained from air-borne samples in a pepper planation that are capable of causing pepper plant diseases. This experiment was conducted at a pepper plantation near Lembah Bidong, Kuala Terengganu. An Andersen spore sampler was used to collect the fungi spores. Culture based identification were then made. The study resulted in the identification of four genus of fungi such as Fusarium sp, Fusarium semictectum Fusarium oxysporum, Curvularia sp., Penicillium sp. and Trichoderma sp. (Ascomycetes). Further molecular identification will confirm the species of fungal pathogens and more understanding of their population as well as severity.
\end{abstract}

Keywords: Pepper, Piper nigrum L., air-borne, fungi, Andersen spore sampler

Copyright : This is an open access article distributed under the terms of the CC-BY-NC-SA (Creative Commons Attribution-Non Commercial-ShareAlike 4.0 International License) which permits unrestricted use, distribution, and reproduction in any medium, for non-commercial purposes, provided the original work of the author(s) is properly cited.

\section{INTRODUCTION}

In Malaysia, pepper plant is identified as one of the national commodities (Chen et al., 2010). Malaysia is the fifth largest pepper producing country in the world with $98 \%$ of the country's annual production coming from the State of Sarawak (Adam et al., 2018). Domestic pepper consumption increased from 12,000 tons in 2014 by $11 \%$ to 13,500 tons in year 2015 as reported by International Pepper Community (IPC) (2014). However, the production of black pepper started falling due to pest and disease occurrence since the early 1980s and it is the main problem faced by growers in Malaysia (Akinsanmi \& Drenth, 2009).

Crop loss due to pests and diseases have resulted in a yearly reduction of about $2 \%$ of the total pepper area (Adam et al., 2018). Several listed diseases of pepper plant such as anthracnose, Phytophthora foot rot, stem rot, fruit rot, mosaic viruses and and Fusarium wilt have been reported and are known to cause economic losses (Shahnazi et al., 2012; Farhana et al., 2013; Farith et al., 2015). In India, Phytophthora foot rot also known as quick wilt is recognized as one of the major causes of low productivity (Thomas, 2017). Additionally, the number of newly described Phytophthora species causing diseases in pepper plants have increased and P. palmivora has been identified as pathogen causing foot rot pepper vines in Malaysia (Brasier, 2008; Farhana et al., 2013; Farith et al., 2015; Habetewold et.al, 2017).

Some fungal pathogens such as Fusarium, Penicillium and Aspergillus which are known to cause stem rot, fruit rot, and wilt can be transferred by air-borne spores or survive in crop debris (Rivka, 2001; Shahnazi et al., 2012). Fungi of the genera Cladosporium, and Penicillium have the ability to produce a lot of spores that they can be found in virtually every cubic meter of air (Wyatt 
et al., 2013).

Dispersal in air is one of many mechanisms by which plant pathogens can spread to new susceptible plants either within the same field or even in a completely different continent (Pady \& Kapica, 2007; West \& Kimber, 2015). Studies available on air-borne fungi pathogen sampling and identification in Malaysia and other Asian countries have mainly been carried out using dust collection methods (Cai et al., 2011; Norbäck et al., 2014), settle plate method (Shams-Ghahfarokhi et al., 2014) and the use of the single-stage viable cascade air sampler (SKC) (Er et al., 2015).

However, the single-stage thermo Scientific Andersen N6 Microbial Sampler used in this study has been reported to be very effective in trapping viable fungi pathogens in polluted air aerosol onto a $100 \times 15 \mathrm{~mm}$ petri dish with agar because of the precision-drilled orifices in its impactor stage, its adjustable stage and the relatively higher flow rate of its pump (Gentry et al., 2012). This study was thus set up to use the Andersen N6 microbial sampler to trap air-borne fungi spore in a pepper plantation near Lembah Bidong, Kuala Terengganu to determine the diversity of air-borne fungi that may cause diseases in the pepper plantation.

\section{MATERIALS AND METHODS}

\section{Field Sampling}

This study was conducted on $6^{\text {th }}$ November 2019 from $3 \mathrm{pm}$ to $6 \mathrm{pm}$ at the only commercial pepper plantation in Lembah Bidong, Terengganu. The plantation follows a strict two weeks fungicide application scheduled hence sampling was carried out one week after fungicide application. A plot of 1.4 hectares was selected for the air-borne fungi sampling to be carried out. The zigzag method of point selection was chosen and in total of fifteen points were sampled (Figure 1). The blocks of pepper plants selected for sampling were $16 \mathrm{~m}$ apart and each block was $220 \mathrm{~m}$ long.

An Andersen N6 Microbial Sampler (Andersen Instruments Inc., USA) was used for the fungi spore sampling. The single stage was adjusted to a height of $1.5 \mathrm{~m}$ and potato dextrose agar (PDA) was exposed on the metal stage. Three sampling replicates were collected at each point and the pump of the sampler was turned on for three minutes.

\section{Isolation of Fungi}

After the air sampling, all the agar plates were incubated at room temperature for 2 to 7 days $\left(27 \pm 2{ }^{\circ} \mathrm{C}\right)$. Different morphology from the fungi colonies such as mycelia formation and pigmentation were isolated. Then spores suspension was prepared and adjusted to concentration of $10^{6}$ by using hemocytometer spores counting. The pure cultures were obtained by growing the single colony of the fungi isolated from the spore suspension prepared. Only pure single colony of fungi were selected for identification (Siti Nordahliawate et al., 2012).

\section{Identification of Fungi}

After 7 to 10 days of incubation, morphological characteristics such as pigmentation and colony formation as well as microscopic characteristics such as conidia spores were observed under the microscope (Klich, 2002; Leslie \& Summerell, 2006; Ellis, 1971). For the microscopic identification, slides were prepared and some small pieces of the pure cultures were cut as well and, observed at $100 \times 10$ magnification using Olympus CX22 (Olympus Corp., Japan) compound microscope.

\section{Diversity of fungi}

Colony-forming units (CFU) from the pure cultures were counted after which fungi diversity was determined. Fungi species diversity was calculated using the Shannon-Weiner Index as shown in Eq. (1) (Spellerberg, 2008).

$H^{\prime}=-\sum_{i=1}^{S} P i \operatorname{In} P i\left(\begin{array}{l}n \\ k\end{array}\right)$

Where: $\sum$ refers to "the sum of" there are s species in the community. $\mathrm{H}$ ' is the value of ShannonWeiner Index. $P i$ is the relative abundance (proportion) of the $i$ species in the community and $\ln$ is the natural $\log$. 


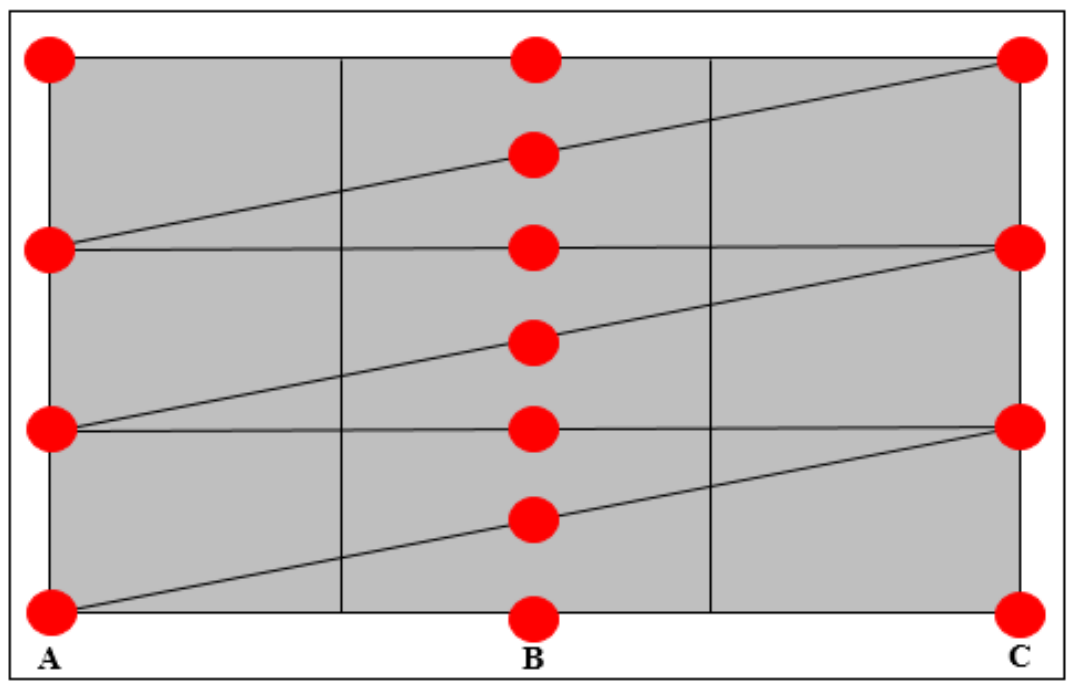

Figure 1. The dots show the zig-zag sampling points where the Anderson spore sampler was located for air sampling in a 1.4 hectares of pepper plantation

\section{RESULTS}

\section{Fungi Identification}

The results showed that a total of four fungi genus of the Ascomycota phylum were identified morphologically. They were Fusarium sp. Curvularia sp. Penicillium sp. and Trichoderma sp. All isolates were easily distinguished by the pigmentation and growth of the pure cultures through visual observation (Figure 2). Isolates identity were confirmed after microscopic observation especially shapes of conidia and other criteria such as conidiophore, phialides and chlamydospore (Figure 3).

We observed that the Fusarium sp. rapidly grow on PDA medium and produced robust woolly mycelium than others (Figure 2a). Microconidia was more common on hyphae growing on the agar. The mode of formation of microconidia, i.e. monophialides or polyphialides as well as the presence of microconidia chains and chlamydospores were observed for Fusarium morphology characteristics identification (Leslie and Summerell, 2006) (Figure 3a). Most of the macroconidia showed a distinct basal foot cell and whereas the microconidia were formed on simple chain with or without branches (Figure 3a). However, some species were observed showing some differences of macroconidia shapes such as $F$. oxysporum showed short with a thin walled and $F$. semitectum showed slender with a curved dorsal surface. Fusarium species are known to cause Fusarium wilt disease of black pepper and in China, it had caused a major decline in pepper production (Xiong et al., 2015). In addition, Shahnazi et al. (2012) had reported that Fusarium species also giving yellowing disease that impact in economic losses at pepper plantations in Malaysia.

The genus Curvularia consists of more than 40 species and its taxonomy changed many times to accommodate species formerly classified as Bipolaris spp. (Zhang et al., 2004; Kusai et al., 2015). The cottony mycelial produced a border shape (regular or irregular) with pigmentation of colony ranges from black, moss green and sometime grey (Figure 2b). Conidia are ellipsoidal (Zhang et al., 2004) (Figure 3b) that could easily be distinguished from the other fungi species such as Fusarium sp., Penicillium sp. and Trichoderma sp. The Curvularia species are well known to cause leaf spot and leaf blight symptoms in maize, rice, beans and cowpea (Liu et al., 2010; Al-Jaradi et al., 2018). Although, little is known about it effects on black pepper nevertheless, there is a potential when conditions are favourable for foliar diseases to develop.

Both Trichoderma sp. and Penicillium sp. were easily distinguished morphologically from their pigmentation and formation on the PDA. The pure culture visually classified as Trichoderma sp. 


\section{Front}

$\mathbf{a}$

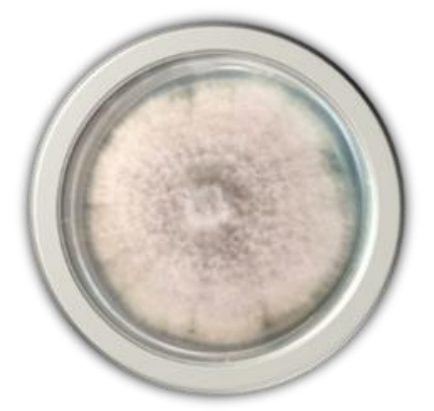

b

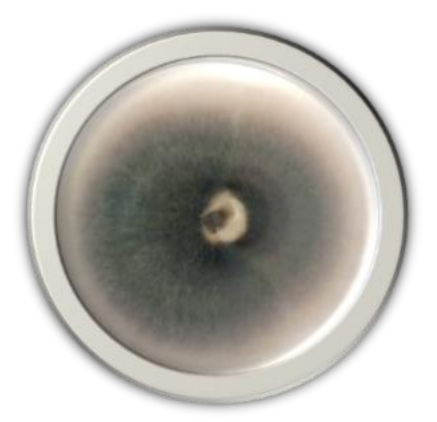

c

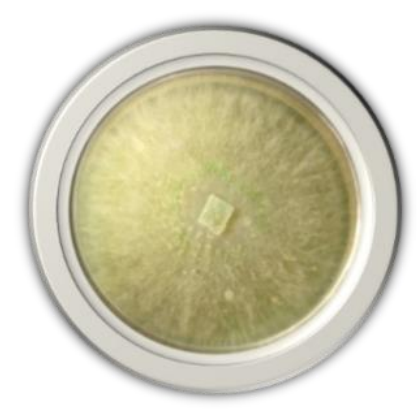

d

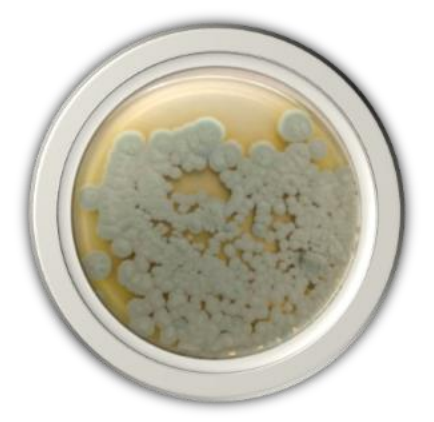

Reverse
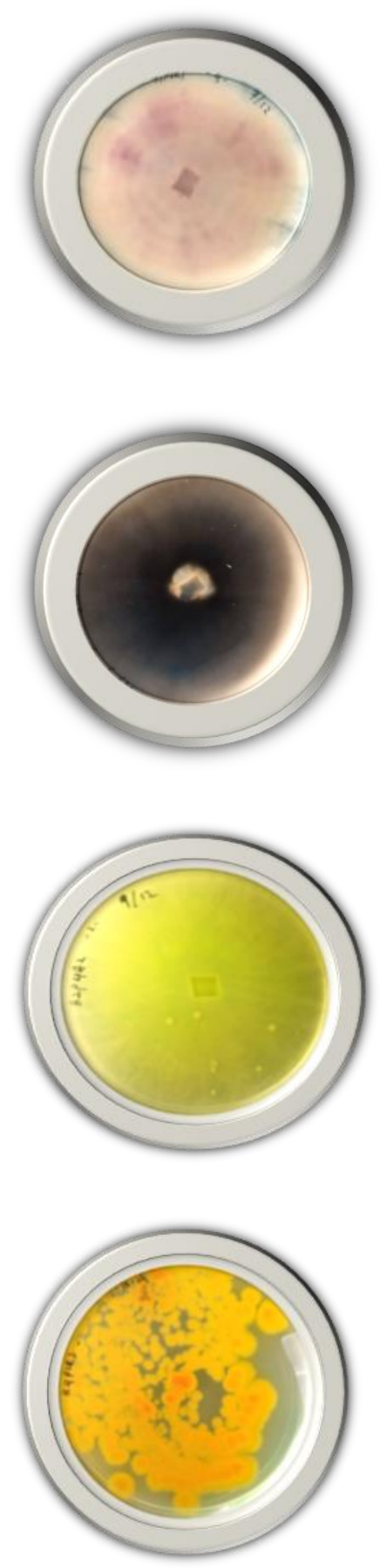

Figure 2. The variation of pigmentation and morphology of the fungal colonies on Potato Dextrose Agar (PDA) medium a) Fusarium sp., b) Curvularia sp., c) Trichoderma sp. and d) Penicillium sp. 


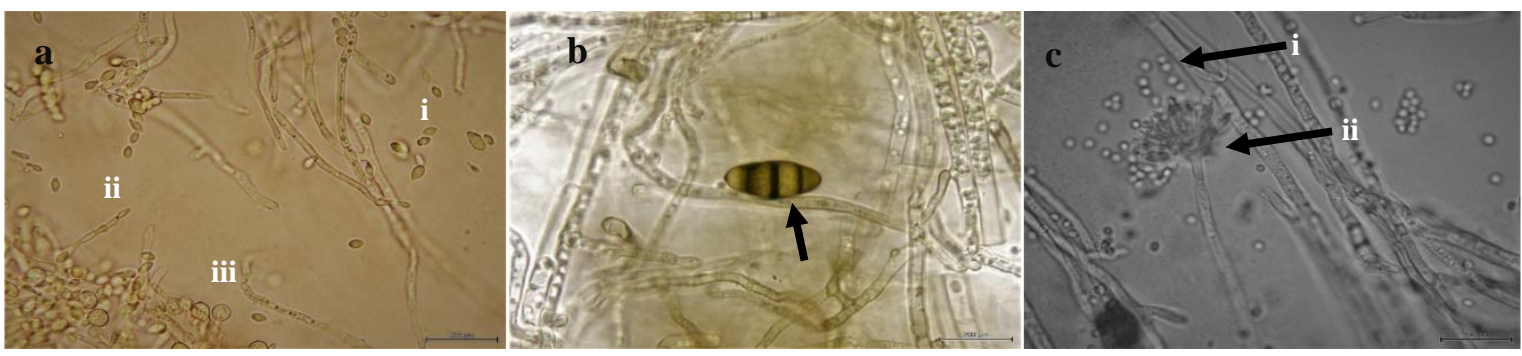

Figure 3. Microscopic characteristics of different fungi under 100 x 10 magnification. a. Fusarium sp. i: microconidia, ii: microconidia chain, iii: chlamydospore b. Curvularia sp. conidia (arrow) and c. Penicillium sp. i: conidia, ii: conidiophores

showed yellowish-light green pigmentation while the pure culture classified as Penicillium showed green pigmentation with white zone on PDA (Figure 2). For Penicillium, the colonies were rapidly growing, filamentous and cottony in texture (Figure 2d) that produced septate hyaline hyphae, branched conidiophores, phialides, and conidia (Figure 3c). Penicillium sp. is well known and also one of the most common fungi appearing in a diverse range of habitats, from soil to vegetation to air, indoor environments and various food product (Frisvad et al., 2004). All the fungi identified in this study are well known plant pathogens whereas Fusarium and Penicillium are known to produce mycotoxins (Agrios, 2005; Perrone \& Susca, 2017; Ji et al., 2019). Trichoderma sp. may cause diseases in other plants but have also been reported to have the ability to reduce the foot rot pathogen Phytophthora capsici in pepper plants (Rajan et al., 2002).

\section{Diversity of Fungi}

The CFU was used to calculate the diversity of the six species that based on the Shannon-Weiner Index. Results showed that Fusarium sp. was the greatest $\left(\mathrm{H}^{\prime}=0.44\right)$ compared to other fungi species (Table 1). Thus, the black pepper plantation area is expected to be infected with Fusarium species when spores are abundance to invade the plant. Several factors may cause the spores abundance such as favourable conditions (weather and humidity) and the susceptible host (Agrios, 2005; Lacey \& West, 2006).

Table 1. Diversity of fungi species at pepper plantation area isolated from air sampling

\begin{tabular}{cccc}
\hline No. & Species $(\boldsymbol{i})$ & Number in sample (CFU) & Species diversity $\left(\boldsymbol{H}^{\prime}\right)$ \\
\hline 1 & Fusarium sp. & 2,071 & 0.44 \\
2 & Fusarium oxysporum & 102 & 0.14 \\
3 & Fusarium semitectum & 7 & 0.02 \\
4 & Curvularia sp. & 3 & 0.00 \\
5 & Trichoderma sp. & 106 & 0.14 \\
6 & Penicillium sp. & 85 & 0.12 \\
\hline
\end{tabular}

\section{CONCLUSION}

This study proved that Fusarium sp. was the dominant fungi species identified compared to other fungi pathogens at the black pepper Lembah Bidong, Terengganu. Several Fusarium species may appear at one area such as in this study, three Fusarium species were identified with distinct morphological characteristics (Fusarium oxysporum and F. semitectum). However, there is limitation in morphological identification when most of the Fusarium species produced similar banana-shaped macroconidia (Leslie \& Summerell, 2006).

Although Fusarium species are well-known 
soil-borne fungi, leaves infection will produce a massive microconidia and/or macroconidia. Consequently, could be dispersed throughout the area by air (Leslie \& Summerell, 2006; West \& Kimber, 2015; Lucas, 2020). All the species of Fusarium identified are known to cause diseases in pepper plants. Fusarium oxysporium causes Fusarium wilt in pepper plants and can cause great economic damage while Fusarium semitectum is reported to cause root rot. Some species of Fusarium are also known to cause leaf yellowing (Shahnazi et al., 2012).

The sampling date and season had favourable conditions for pathogen germination. This support the disease triangle concept which sates the importance of host, environment and pathogen for a disease to appear consequently resulting in disease epidemic (Agrios, 2005; Lucas, 2020). The mechanism of spores disperses such as tap and hail, will increase fungal pathogens infection at the field (Magyar et al, 2016). Therefore, by knowing the number of spores and species of fungi in the air will contribute to control measures instituted by the plantation. Moreover, it will help in decision making of the plantation especially in chemical control such as fungicides. A study by Siti Nordahliawate et. al, (2012) showed monitoring of air-borne spores and weather conditions can accurately predict when fungicide application maybe necessary.

At the field, air-borne spores contain several different fungi species that could be easily disseminated by wind blowing. Therefore, molecular approach could confirm the species when morphology identification shows a high degree of similarity and may cause misidentification. We believe that this study will benefit the pepper plantation to further monitor the air-borne fungi surrounding the field that may cause economically important diseases.

\section{ACKNOWLEDGEMENTS}

We thank Dr. Nik Mohd Izham, School of Biological Sciences, USM Penang for his guidance on Andersen air sampler and the black pepper plantation staff at Lembah Bidong, Terengganu for their technical assistance.

\section{REFERENCES}

Adam, A., Kho, P. E., Sahari, N., Tida, A., Chen, Y. S., Tawie, \& Mohamad, H. (2018). Dr. LADA:
Diagnosing black pepper pests and diseases with decision tree. International Journal on Advanced Science, Engineering and Information Technology, 8(4-2), 1584.

Agrios, G. (2005) Plant Pathology. 5 ${ }^{\text {th }}$ Ed., Elsevier Academic Press, Amsterdam.

Akinsanmi, O. \& Drenth, A. (2009). Phytophthora diseases management. Australian Macadamia Society Ltd. News Bulletin, 36. 32-34.

Al-Jaradi A., Al-Mahmooli I., Janke R., Maharachchikumbura S., Al-Saady N. \& Al-Sadi A.M. (2018). Isolation and identification of pathogenic fungi and oomycetes associated with beans and cowpea root diseases in Oman. PeerJ Journal 6: e6064. DOI: 10.7717/peerj.6064

Andersen, A.A. (1958) A new sampler for the collection, sizing and enumeration of viable air-borne particles. Journal of Bacteriology, 76(5): 471-484.

Brasier C., (2008). Phytophthora Biodiversity: How Many Phytophthora Species Are There? In Goheen, E.M. \& Frankel, S.J. (eds) Phytophthoras in Forests and Natural Ecosystems. Proceedings of the Fourth Meeting of the International Union of Forest Research Organizations (IUFRO) Working Party S07.02.09101. August 26-31, 2007, Monterey, California. pp. 101-115

Cai G.H., Hashim J.H., Hashim Z., Ali F., Bloom E., Larsson L., Lampa E. \& Norback D. (2011). Fungal DNA, allergens, mycotoxins and associations with asthmatic symptoms among pupils in schools from Johor Bahru, Malaysia. Pediatric Allergy and Immunology, 22: 290-297. DOI: 10.1111/j.13993038.2010.01127.x

Chen, Y.S., Dayod, M., Tawan, C.S. \& Science, F. (2010). Phenetic Analysis of Cultivated Black Pepper (Piper nigrum L.) in Malaysia. International Journal of Agronomy, 45(1), 43-47.

Ellis, M.B. (1971). Dematiaceous hypomycetes, commonwealth agricultural bureaux. Slough, England: Farham Royal, p. 440.

Er, C.M., Sunar, N.M., Leman, A.M. \& Othman, N (2015). Direct growth inhibition assay of total airborne fungi with application of biocide-treated malt extract agar. MethodsX, 2: 340-344. DOI: 10.1016/j.mex.2015.07.002

Farhana, S.N.M.D, Rahamah, B.M., Khairulmazmi, A., Wong S.K. \& Sariah, M. (2013). Morphological and molecular characterization of Phytophthora capsici, the Causal Agent of foot rot disease of black pepper in Sarawak, Malaysia. International 
Journal of Agriculture \& Biology, 15: 1083-1090.

Farith M.K., Awang, A.S.A.H., Lihan, S. Mohd, H.M. H. \& Hairul, A.R. (2015). In vitro antagonism of Phytophthora capsici and Fusarium solani by bacterial isolates from Sarawak. Malaysian Journal of Microbiology, 11(2): 137-143.

Frisvad, J.C., Smedsgaard, J. \& Larsen, T.O. (2004). Mycotoxins, drugs and other extrolites produced by species in Penicillium subgenus Penicillium. Studies in Mycology, 49: 201-241.

Gentry, R.F., Mitrovic, M. \& Bubash, G.R. (2012). Application of Andersen Sampler in Hatchery Sanitation. Poultry Science, 41(3): 794-804.

Kifelew, H., Adugna, G. \& Tilahun, D. (2017). Reaction of black pepper (Piper nigrum $\mathrm{L}$ ) accessions against Phytophthora capsici in Ethiopia, proceedings of the fifth biennial conference of Ethiopian Horticultural Science Society (EHSS), Volume V.14-15 February 2015, Samara, Ethiopia.

Ji, F., He, D., Olaniran, A.O., Mokoena, M.P., Xu, J. \& Shi, J. (2019). Occurrence, toxicity, production and detection of Fusarium mycotoxin. Food Production, Processing and Nutrition, 1, 6. DOI: $10.1186 / \mathrm{s} 43014-019-0007-2$

Klich, M. A. (2002). Identification of common Aspergillus species. $1^{\text {st }}$ Edition. Utrech, Netherlands. Centraalbureau voor Schimmelcultures (CBS). Pp. 140.

Kusai, N.A., Mior. Z., Azmi, M., Zulkifly, S., Yusof, M.T. \& Mohd Zainudin, N.A.I. (2015). Morphological and molecular characterization of Curvularia and related species associated with leaf spot disease of rice in Peninsular Malaysia. Rendiconti Lincei, 27(2): 205-214.

Lacey, M. \& West, J. (2006). The air spora - A manual for catching and identifying airborne biological particles. Dordrecht, the Netherlands. Springer Publishing Company Ltd. DOI: 10.1111/j.13653059.2007.01610.x

Leslie, J.F. \& Summerell, B.A. (2006). The Fusarium laboratory manual. Iowa, USA, Blackwell Publishing. Pp. 388.

Liu, T., Liu, L., Jiang, X., Huang, X. \& Chen, J. (2010). A new furanoid toxin produced by Curvularia lunata, the causal agent of maize Curvularia leaf spot. Canadian Journal of Plant Pathology, 31 (1): 22-27. DOI: 10.1080/07060660909507568.
Lucas, J. A. (2020). Plant Pathology and Plant Pathogens, $4^{\text {th }}$ Edition, Wiley-Blackwell. 432.

Magyar, D. \& Vass, M. \& Li, D.W. (2016). Dispersal Strategies of Microfungi. In Li, D.W. (eds.), Biology of Microfungi, Fungal Biology. Switzerland, Springer International Publishing. DOI 10.1007/978-3-319-29137-6_14.

Martin, R.R., James D. \& Le'vesque, C.A. (2000). Impacts of molecular diagnostic technologies on plant disease management. Annual Review of Phytopathology, 38: 207-239.

Shams-Ghahfarokhi, M., Aghaei-Gharehbolagh, S., Aslani, N. \& Razzaghi-Abyaneh M. (2014). Investigation on distribution of airborne fungi in outdoor environment in Tehran, Iran. Journal of Environmental Health Science \& Engineering, 12, 54. DOI: $10.1186 / 2052-336 X-12-54$

Norbäck, D., Markowicz P., Cai, G-H., Hashim, Z., Ali, F. \& Zheng, Y-W. (2014) Endotoxin, Ergosterol, Fungal DNA and Allergens in Dust from Schools in Johor Bahru, Malaysia- Associations with Asthma and Respiratory Infections in Pupils. PLoS ONE, 9, 2. DOI: 10.1371/journal.pone.0088303

Pady, S.M., \& Kapica, L. (2007). Fungi in Air over the Atlantic Ocean. Mycologia, 47(1): 34-50. DOI: $10.2307 / 3755754$

Perrone, G. \& Susca, A. (2017). Penicillium Species and their associated mycotoxins. In Moretti, A. and Susca, A. (eds) Mycotoxigenic Fungi: Methods in molecular biology, Vol 1542. New York, Humana Press.

Rajan P, Sarma Y.R. \& Anandaraj, M. (2002) Management of foot rot disease of black pepper with Trichoderma spp. Indian Phytopath, 55 (1): 34-38.

Rivka, B.G., (2001). Chapter 5 - Attack Mechanisms of the Pathogen, Postharvest Diseases of Fruits and Vegetables. Elsevier, Amsterdam, pp. 54-65.

Shahnazi, S., Meon, S., Vadamalai, G.K. Ahmad, K. \& Nejat, N. (2012). Morphological and molecular characterization of Fusarium spp. associated with yellowing disease of black pepper (Piper nigrum L.) in Malaysia. Journal of General Plant Pathology, 78 (3): 160-169. DOI: 10.1007/s10327012-0379-5

Siti Nordahliawate M.S., Yong-Ju H., Avice, M.H. \& Bruce D.L. F. (2012). Maturation of Leptosphaeria 
maculans and L. biglobosa pseudothecia and first appearance of phoma leaf spots on winter oilseed rape. Aspects of Applied Biology, 117: 209-215.

Siti Nordahliawate, M.S., Nur Ain, I.M.Z., Nur Azlin, A. \& Baharuddin, S. (2012). Diversity of Fusarium species isolated from soil cultivated with cucurbits within East Coast, Peninsular Malaysia. Pertanika Journal of Tropical Agricultural and Sciences, 35 (2): 381-386.

Spellerberg, I.F. (2008). Encyclopedia of Ecology (p.3249-3252). New Zealand: Lincoln University, Lincoln.

Thomas, L. M. (2017). Survey for the Incidence of Foot Rot of Black Pepper Caused by Phytophthora capsici Leonian in Shivamogga and Chickmagaluru Districts of Karnataka State. International Journal of Pure \& Applied Bioscience, 5(1): 293-298.
Watanabe, T. (2002). Pictorial atlas of soil and seed fungi: morphologies of cultured fungi and key to species. Boca Raton, CRC Press. DOI: $10.1201 / 9781420040821$

West, J. S., \& Kimber, R.B.E. (2015). Innovations in air sampling to detect plant pathogens. Annals of Applied Biology, 166(1): 4-17.

Wyatt, T.T., Wösten, H.A.B., \& Dijksterhuis, J. (2013). Fungal spores for dispersion in space and time. In Sariaslani, S. \& Gadd G.M. (eds) Advances in Applied Microbiology, 85: 43-91. DOI: 10.1016/B978-0-12-407672-3.00002-2

Xiong, W., Li, Z., Liu, H., Xue, C., Zhang, R. \& Wu, H. (2015) The effect of long term continuous cropping of black pepper on soil bacterial communities as determined by 454 pyrosequencing. PLOS ONE, 10 , 8. DOI: 10.1371/journal.pone.0136946

Zhang, M., Zhang, T.Y. \& Wu, W.P. (2004). A new name and a new variety in Curvularia. Mycosystema, 23, 177-178. 